\title{
Rapid Assessment for Livestock Disease Mapping in Ojojie Integrated Water Shed Management Doyogena, District of Southern Ethiopia
}

\author{
Melese Yilma $^{1 *}$, Fitsum Tessema ${ }^{1}$, Tewodros Getachew ${ }^{1}$, Tucho Tumato ${ }^{1}$, Shimelis Mengistu ${ }^{1}$, Tsegay Bekele ${ }^{1}$, Addisu Jimma $^{1}$ and Asrat Tera ${ }^{2}$ \\ ${ }^{1}$ Areka Agricultural Research Center, Areka, PO Box 79, Ethiopia \\ ${ }^{2}$ Southern Agricultural Research Institute, Hawassa, PO Box 06, Ethiopia
}

“Corresponding author: Melese Yilma, Areka Agricultural Research Center, PO Box 79, Areka, Ethiopia, Tel: +251910755190; E-mail: melese.yilma@yahoo.com

Rec date: Jul 24, 2015; Acc date: Jan 28, 2016; Pub date: Jan 30, 2016

Copyright: @ 2016 Yilma M, et al. This is an open-access article distributed under the terms of the Creative Commons Attribution License, which permits unrestricted use, distribution, and reproduction in any medium, provided the original author and source are credited.

\begin{abstract}
The objective of this paper was rapid assessment of major health problem for disease mapping on integrated water shad management system and the study was undertaken in farmers dissection group formed in the water shade delineated site ojojie model water shade. As to livestock production constraint disease challenge was most important next to feed and indigenous breed genetic performance in the management system. In the area as to the major livestock production constraint season play great role in association with rainfall pattern. Overstocking in the pasture and traditional husbandry practice provoke livestock disease challenge and outbreak in the management system. For the herd entry and exit rout birth, market, family gift, outbreak mortality (natural death lose) and government and NGO program was identified as the main source for disease and infection challenge in the management system. Seasonal disease distributions and livestock production variation is manly associate with the disease enzootic stability, feed gap, and environmental condition variability. The study was first report to the area can be used as bench mark for disease laboratory diagnosis and conformation.
\end{abstract}

Keywords: Livestock; Health problem; Water shed; Ojojie

\section{Introduction}

Animal diseases continue to constrain livestock productivity, agricultural development, human well-being and poverty alleviation in many regions of the developing world. There are some diseases that affect all regions of the world and all sectors of the community and there are some that are of particular importance, individually and collectively to the very poor. These are diseases that affect the particular species of animals that have special importance to poor societies. Include diseases that affect the human populations of these poor societies themselves and causing death, disability and suffering so creating a barrier to escape from poverty [1].

In general livestock diseases are grouped in to endemic, epidemic (Tran's boundary), zoonotic and foodborne. Animal diseases generate a wide range of biophysical and socio-economic impacts that may be both direct and indirect, and vary from localized to global problems. Particularly useful distinction can be made between those impacts associated with overt disease and those associated with disease risk [2].

When animal disease occurs, there are several different types of commonly recognized impacts the most important and readily measurable direct effects of diseases are manifest by losses in productivity. These include the effects of death, illness leading to condemnation, poor weight gain, poor milk yield, poor feed conversion, poor reproductive capacity and poor work capacity for draft and packing animals. Diseases of livestock have additional indirect impacts this impact is often highly under-estimated, and has generally been poorly quantified.

Reduction or elimination of market opportunities outbreaks of infectious diseases in a community or a region may result in local market disruptions as movement restrictions are imposed, with farmers unable to market livestock and livestock products with optimal timing such as moving fattener to marketers at all for example restricting milk collection, or they may face dramatically depressed prices. The mere occurrence of certain diseases can also severely constrain cross-border and other international trade, and is most commonly associated with the highly infectious diseases such as Foot and mouth disease, Newcastle disease and the epidemic zoonosis such as Rift valley fever [3].

Diseases of livestock have many additional direct and indirect impacts on human nutrition, community development and sociocultural values and illness in people associated with zoonotic and foodborne diseases leads to losses in their productivity and quality of life, as well as costs incurred for treatment [4]. Livestock diseases that inflict major socio economic losses in Ethiopia occur every year. Annual disease losses amount to $8-10 \%, 14-16 \%$, and $11-13 \%$ of the cattle, sheep and goat populations, respectively. It is estimated that some 700 million Birr ( 1 US $\$=9.2$ Birr) is lost annually due to helminthes (internal parasite) infestation of domestic animals [5]. Besides affecting the quantity and quality of livestock products, the prevalence of infectious and economically important animal diseases in Ethiopia excludes the country from profitable international markets, thereby greatly reducing the country's foreign exchange earnings. Poor husbandry practices and inadequate veterinary services are the major factors favoring the expansion of livestock diseases [6].

\section{Methodology}

The watershed is located in Doyogena Woreda of Kembata Tambaro zone. The total population of the Woreda is 116,048 . The total area of the woreda is estimated to be $18,091.34$ ha which comprises cultivated land (12,248.6 ha), forest land (3573 ha), grazing land (1110 ha), degraded land (435 ha), swampy land (358.33 ha), potentially cultivable land (202.4 ha) and others (162.4 ha). The woreda has 
Citation: Yilma M, Tessema F, Getachew T, Tumato T, Mengistu S, et al. (2016) Rapid Assessment for Livestock Disease Mapping in Ojojie Integrated Water Shed Management Doyogena, District of Southern Ethiopia. J Veterinar Sci Technol 7: 300. doi: $10.4172 / 2157-7579.1000300$

Page 2 of 7

diverse agro-ecologies out of which 15\% Dega, 74\% W/Dega and 11\% Kolla. Rainfall distribution of the Woreda ranges from $850 \mathrm{~mm}$ to 1200 $\mathrm{mm}$ and $20^{\circ} \mathrm{C}$ to $25^{\circ} \mathrm{C}$ average annual temperature. The altitude ranges from 1900-2010 masl. Teff, wheat, haricot bean, maize, sweet potato and irish potato are the major crops of the woreda. Other crop like field pea and faba bean are also produced in limited amount [7] (Figure 1).

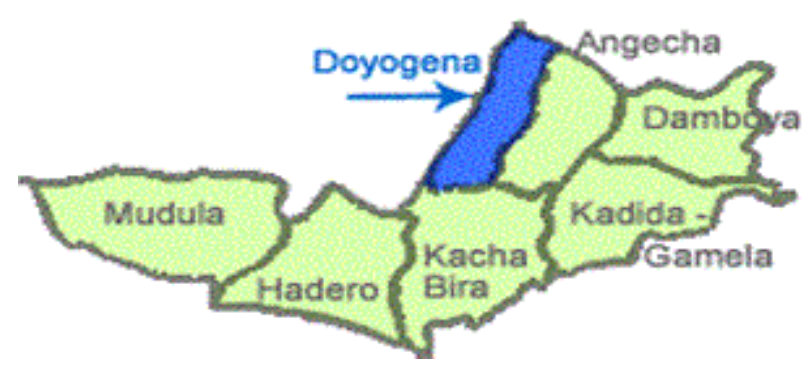

Figure 1: Map of Doyogena district with in Kembata-Tambaro zone (Source: Doyogena District BoA).

From three Kebele (Ancha, Gomora and Wagabata) farmers group in the watershed were considered for the study. Sample of farm households from the three Kebele were selected using random sampling technique using list of households which was obtained from Kebele's in the watershed. To ensure representation of female headed households in the sample, farmers in each group were stratified into male and female headed households and $22 \%$ of samples to be female headed; however, number of female headed households in the three groups was so negligible that only few cases were considered. Hence, a total of 6 sample households, 2 from each Keble's were selected for three farmer's discussion group.

\section{Data Collection}

The primary data was collected from sample households with farmer's discussion group and structured PRA tool was employed. A team of researchers and technical assistants from animal science research case team were given an orientation on the PRA tool. Thus, they had consent to undertake the data collection under close supervision. The study also considered information from secondary sources such as previous project research report, woreda office of agriculture, and related literature. The data collected for the study encompasses information regarding livestock disease and economic importance, zoonosis and animal source human nutrition on integrated water shed management and livestock composition. The field survey was conducted during Jun, 2013.

\section{Results}

\section{Livestock production seasonal calendar during the past one year}

In the study area farmers used to rear different type of livestock. The main livestock types were cattle, small ruminants, poultry and to some extent draft animals such as horse, mule and donkey. Only few farmers had bee hive. There is difference on the number of breeding ram and oxen between farmers in the three groups.
Livestock productions vary during the year [especially fattener and breeder] with respect to seasons where there is less feed available and production decline in association with livestock health challenge in the management system the root cause is high / low rainfall distribution in the seasons where there is less livestock feed is available in the community. Livestock reproduction cycle dramatically increases in association with start of school year and festivals this is due to increase demand for animal source protein in the community [household consumption] (Figure 2).

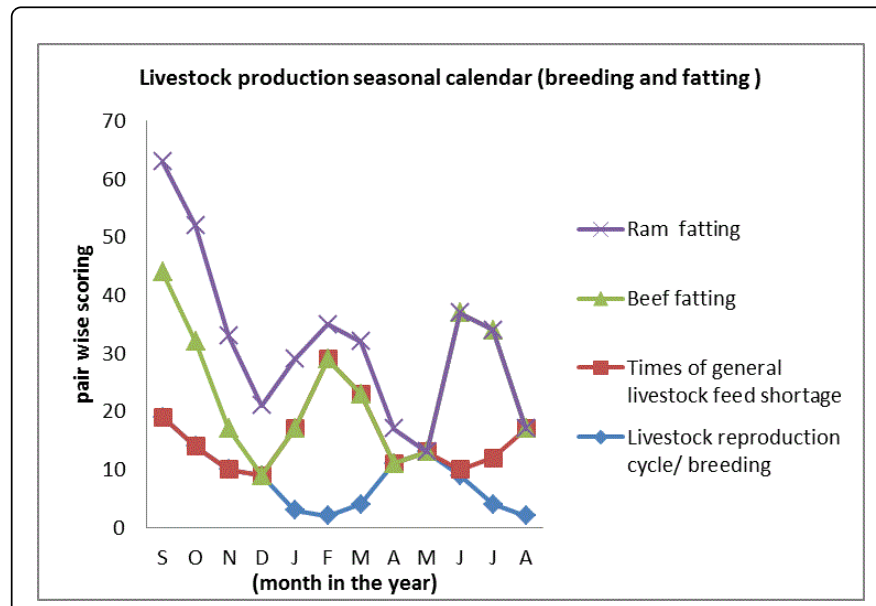

Figure 2: Livestock production seasonal calendar breeding and fatting $(\mathrm{n}=100)$.

Seasonally September, October, November, April and May the livestock reproduction is peak which is mainly associated with feed (quality pasture and abounded crop residue as to livestock feed), water availability and suitable environmental condition. On the other hand in January, February and March livestock production decrease in quality and quantity which is heated by high morbidity and mortality due to livestock disease, degraded grazing and pasture quality and pasture contamination with fecal and harbors parasitic larvae and egg. August is time of planting crop so livestock breeding decreases since animal are allowed indoor feeding there is no accuses for observing heat sign and mating which reduce fertility. January, February and March is time of general feed shortage and those only feed source is enset leaf, pseudo stem, corms and crop residue (wheat straw, barely straw).

Following the MESKELE festival, beef fattening will start June and finish on September this is indicated in the Figure 1 above and from December, January, February, March, April and May beef fattening is not practiced due to high feed / finishing cost, seasonally this is a period of cultivation so farmers intensively use oxen for draft power and endemic disease challenge.

May to August sheep fattening is not suitable as these months are cool and also high contamination of the pasture with parasite egg which is manifested by poor feed conversion and low weight gain. In this season liver fluke (MURY) is the major challenge in Wasara and kachara Gott unlike high tick infestation but to that of Jana and Anch. 1 and 2 Gott the main challenge is high tick and egg infestation on the animal and pasture and in addition high finishing cost ram, fattening is not practical (Figure 3). 
Citation: Yilma M, Tessema F, Getachew T, Tumato T, Mengistu S, et al. (2016) Rapid Assessment for Livestock Disease Mapping in Ojojie Integrated Water Shed Management Doyogena, District of Southern Ethiopia. J Veterinar Sci Technol 7: 300. doi: $10.4172 / 2157-7579.1000300$

Page 3 of 7

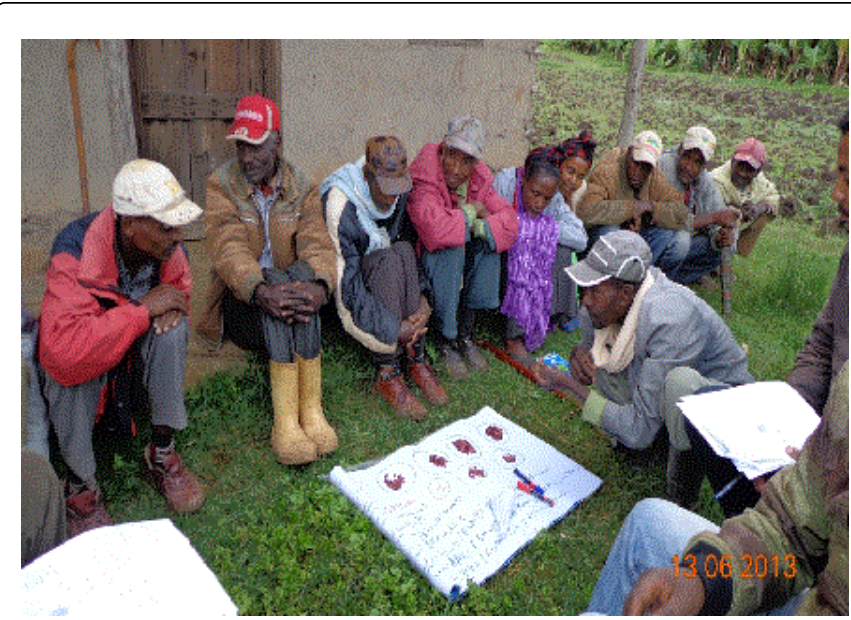

Figure 3: Farmer discussion group while data captured on livestock production seasonal calendar (photo source: Melese Yilma).

\section{Farmers' perceptions to the main constraints to production of livestock in the integrated water shed management system}

According to this study, livestock disease challenge and seasonality in feed availability, water shortage typically long watering point, land topography and accidental death of productive cows, culling of productive caws due to accident / involuntary culling, poor livestock technology adoption and management practice, land shortage for planting improved forges, livestock market problem manifested in the presence of large number of middle men and poor genetic potential of the local genotypes were rated as the major livestock production constraints in the watershed. The top five ranked constraints were disease, feed shortage in seasons, water shortage and poor livestock technology adoption. The constraint that was identified as most important is shortage of potable water, poor genetic potential of the indigenous livestock and disease challenge (Table 1).

\begin{tabular}{|c|c|c|c|c|c|c|c|c|c|c|c|c|}
\hline S No & Data capture & 1 & 2 & 3 & 4 & 5 & 6 & 7 & 8 & 9 & Score & Rank \\
\hline 1 & Disease / health challenge & & 2 & 1 & 1 & 5 & 1 & 1 & 1 & 2 & 5 & 3 \\
\hline 2 & Feed problem / shortage in seasons & & & 3 & 2 & 2 & 6 & 7 & 2 & 3 & 5 & 3 \\
\hline 3 & Water shortage / no or long watering point & & & & 3 & 3 & 3 & 3 & 3 & 9 & 7 & 1 \\
\hline 4 & Land topography / Accidental death, culling of caws & & & & & 5 & 6 & 7 & 4 & 9 & 1 & 6 \\
\hline 5 & Poor / gap on livestock technology adoption & & & & & & 5 & 5 & 5 & 9 & 4 & 4 \\
\hline 6 & Poor / gap on livestock technology adoption & & & & & & & 6 & 6 & 9 & 4 & 4 \\
\hline 7 & Land shortage / for planting improved forge plant & & & & & & & & 7 & 9 & 3 & 5 \\
\hline 8 & Livestock market problem / middle man & & & & & & & & & 9 & 0 & 7 \\
\hline 9 & Improved breed / poor performing local breed & & & & & & & & & & 6 & 2 \\
\hline
\end{tabular}

Table 1: Pair-wise ranking Farmers perception for the main livestock production constrain in the water shed. Data collected from a pair wise ranking from three focus group discussions $(n=100)$.

\section{Water shortage / no or long watering point}

Water source for livestock in the water shed include spring, river, hand dug well and community ponds. More than $90 \%$ of farmers in all focus discussion group responded that the main source of water for human and livestock use is spring. More than $83 \%$ of farmers in the groups responded that ownership of water sources mainly belongs to the community. For the majority of farmers the water sources exist throughout the year (annual), which implies, in the area there is no serious water source problem. Even though, the water sources are community resources (hand dug well, springs and community ponds), there is no water utilization bylaw which is an important tool for sustainable use of the water [7].

Water source is abundant and not problem in the management system. However it is critically indicated by the Wasera and Kechera farmer's discussion group that long journey for livestock watering point to the Hadiya border with related travelling stress; uncontrolled livestock movement to the water point and animal congregation at the area and water source contamination is main problem for the livestock production. Besides, to this at the congregation pointe contagious disease (Hemorrhagic septicemia), water source and environmental pollution are the main challenge in the area.

\section{Improved breed / poor genetic performing local breed}

In the management system $99 \%$ livestock population are local / indigenous and are low in the genetic performance. To improving the milk production the cost for heifer seed source is high and gap in use and adoption of reproductive biotechnology (artificial insemination and induced synchronization plus artificial insemination). Poultry high mortality of exotic day old chicken and predator challenge are serious problem for poultry improvement in the system.

\section{Disease and health challenge}

Due to traditional husbandry practice on the communal grazing pasture in dry season due to over stocking and pasture contamination 
Citation: Yilma M, Tessema F, Getachew T, Tumato T, Mengistu S, et al. (2016) Rapid Assessment for Livestock Disease Mapping in Ojojie Integrated Water Shed Management Doyogena, District of Southern Ethiopia. J Veterinar Sci Technol 7: 300. doi: $10.4172 / 2157-7579.1000300$

Page 4 of 7

soil born disease (Anthrax and B-leg) and toxic plant (LAKESSA and SODDO NAKALLA) in the system livestock disease and health challenge caused sudden death and heavy loss in the past years (Figure $4)$.

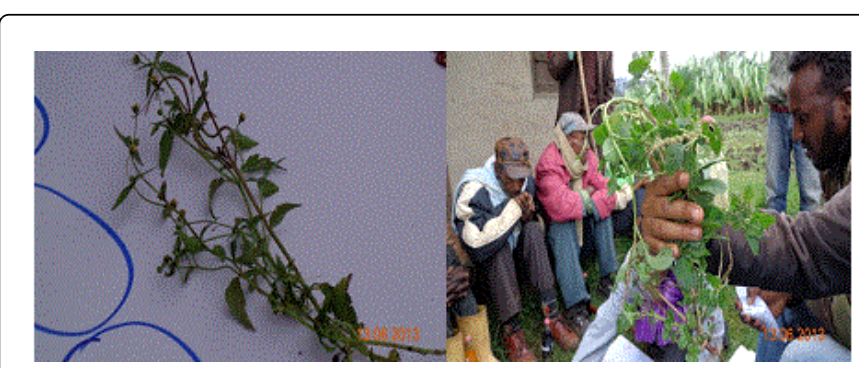

Figure 4: Toxic plant species identified by the Farmer discussion group us major challenge in the area (photo source: Melese Yilma).

As to the wet season high tick, mange mite and other external parasitic challenge and liver fluke (MURYA) disobey the livestock production system in the area. Due to infection by toxic plant
(LAKESSA) and fluke (MURYA) livestock market price is deplored due to liver infection, condemnation of organ and poor BCS of the live oxen.

\section{Livestock morbidity and mortality (availability and risk) herd (entry / exit)}

Health risks versus nutrition benefits around consumption of sick and/or dead animals and flock dynamics in association livestock morbidity and mortality. The beans counters in this circle represent all the stock present ill age or community at the start of the year. First we want to look at the proportion which enters the herd. How do they obtain their animals during the course of the year the sources are Market / purchase, gift, government program (Areka Agricultural Research center / SARI), Breeding / birth, NGO (Irish aid OR, Productive seftyt-net program / PSNP / and traditional arrangement in which one directly shares one third of the animal in question (SISSO). Secondly, we want to look at the proportion which leaves the herd. The different reasons for livestock move out are sold, gift, stolen, death, predator, accident due to the land topography and culling of nonproductive and aged animal from the stock (Tables 2-7).

\begin{tabular}{|c|c|c|}
\hline Data captured & Proportion & Other \\
\hline Livestock source & $(n=200)$ & \\
\hline Market / purchase & 31 & \\
\hline Breeding / by birth & 65 & \\
\hline Gift & 26 & Traditional practice in the area \\
\hline Government & 17 & SARI / Areca agricultural research center and wereda BoA. \\
\hline NGO & 16 & PSNP and Irish aid OR \\
\hline Traditional practice / SISSO & 45 & Traditional livestock sharing arrangement in the area \\
\hline Reason for livestock move out & $(n=200)$ & \\
\hline Sold & 98 & \\
\hline Gift & 12 & Traditional practice in the area especially marriage time \\
\hline Stolen & 12 & \\
\hline Death & 40 & Root cause for death are disease, accident and environment \\
\hline Predator & 11 & high mortality of the day old chicken \\
\hline Accident & 13 & Mainly associated with the land topography \\
\hline Culling & 14 & Reproductive problem, poor performance and age of animal \\
\hline Remaining stock & $(n=20)$ & \\
\hline Breeding & 4 & For replacement stock \\
\hline Draft & 3 & Mainly cattle and equine \\
\hline Milk & 3 & Caw \\
\hline Security & 3 & Ruminate and poultry \\
\hline Household protein / consumption & 7 & Typically animal source food \\
\hline
\end{tabular}

Table 2: Herd dynamics of the livestock production in the integrated water shed management system. 
Citation: Yilma M, Tessema F, Getachew T, Tumato T, Mengistu S, et al. (2016) Rapid Assessment for Livestock Disease Mapping in Ojojie Integrated Water Shed Management Doyogena, District of Southern Ethiopia. J Veterinar Sci Technol 7: 300. doi: 10.4172/2157-7579.1000300

Page 5 of 7

\begin{tabular}{|c|c|c|c|c|c|c|c|}
\hline Data capture & $\begin{array}{l}\text { Disease } \\
1\end{array}$ & Disease 2 & Disease 3 & Disease 4 & Disease 5 & Disease 6 & Disease 7 \\
\hline Local name & Heticho & Bobro & Shilgiko & Angicho & $\begin{array}{l}\text { Keste- } \\
\text { damena }\end{array}$ & Murya & Gandeya \\
\hline Clinical signs & $\begin{array}{l}\text { Air born, } \\
\text { sudden } \\
\text { death }\end{array}$ & $\begin{array}{l}\text { Fever, } \\
\text { shivering, } \\
\text { lameness }\end{array}$ & $\begin{array}{l}\text { Mucous and } \\
\text { blood on faeces, } \\
\text { sometime dry } \\
\text { faeces }\end{array}$ & $\begin{array}{l}\text { Tung is not } \\
\text { flexible, } \\
\text { excessive } \\
\text { salvation, } \\
\text { fever }\end{array}$ & $\begin{array}{ll}\text { Red } & \text { urine, } \\
\text { dry } & \text { fasces, } \\
\text { depression } \\
\text { and } & \text { poor } \\
\text { BCS } & \end{array}$ & $\begin{array}{l}\text { Emaciation, } \\
\text { diarrhea, PM } \\
\text { worm on the } \\
\text { liver }\end{array}$ & $\begin{array}{l}\text { Emaciation, } \\
\text { reduced draft } \\
\text { power, depressed } \\
\text { and death }\end{array}$ \\
\hline Common name & Anthrax & B-leg & Salmonellosis & Wooden tong & Babesiosis & Liver fluke & Trypanosomasis \\
\hline Condition and age group of animal affected & $\begin{array}{l}\text { All age } \\
\text { group }\end{array}$ & $\begin{array}{l}\text { Well-fed } \\
\text { animal }\end{array}$ & All age & All age & All age & Adult & All age \\
\hline Seasonality of occurrences & $\begin{array}{l}\text { Dry } \\
\text { season }\end{array}$ & $\begin{array}{l}\text { Dry season } \\
\text { Oct. Nov }\end{array}$ & -nil & $\begin{array}{l}\text { Throughout } \\
\text { the year }\end{array}$ & $\begin{array}{l}\text { Dry seasons } \\
\text { with feed } \\
\text { shortage } \\
\text { toxic plant } \\
\text { RASSO }\end{array}$ & $\begin{array}{l}\text { Wet and rainy } \\
\text { season }\end{array}$ & Dry season \\
\hline Breed of animal affected & All & All & Nil & All & Local & Local & All \\
\hline Main effect of the disease & Death & $\begin{array}{l}\text { Death if not } \\
\text { treated }\end{array}$ & $\begin{array}{l}\text { death, weight } \\
\text { loss }\end{array}$ & weight loss & Death & weight loss & death, weight loss \\
\hline Ethology & $\begin{array}{l}\text { Air born } \\
\text { and } \\
\text { climate } \\
\text { change }\end{array}$ & -air & Contamination & - & $\begin{array}{l}\text { Dry seasons } \\
\text { with feed } \\
\text { shortage } \\
\text { toxic plant } \\
\text { RASSO }\end{array}$ & $\begin{array}{l}\text { Worm on the } \\
\text { pasture }\end{array}$ & - \\
\hline $\begin{array}{l}\text { Treatment and prevention measures / ethno } \\
\text { vet practice }\end{array}$ & Nil & $\begin{array}{l}\text { Cutting on } \\
\text { the back, } \\
\text { bleeding and } \\
\text { burning } \\
\text { WORBEBO } \\
\text { leaf }\end{array}$ & Nil & $\begin{array}{l}\text { Raving the } \\
\text { Tung with dry } \\
\text { dung and } \\
\text { fumigation } \\
\text { with egg shell } \\
\text { + dung + Feto } \\
\text { leaf }\end{array}$ & Nil & Tablet & Vet service \\
\hline Degree of effectiveness of the treatment & & *** & & *** & & *** & * \\
\hline
\end{tabular}

Table 3: List of most common endemic diseases of cattle. Very effective ${ }^{* * *}$; a little bit effective*.

\begin{tabular}{|c|c|c|c|c|c|c|c|}
\hline Data capture & Disease 1 & Disease 2 & Disease 3 & Disease 4 & Disease 5 & Disease 6 & Disease 7 \\
\hline Local name & Gansho & Lomicho & Bokomosso & Kurkussa & Batarnna & Murya & Elamosso \\
\hline Clinical signs & $\begin{array}{l}\text { Nasal } \\
\text { discharge, } \\
\text { coughing } \\
\text { and PM } \\
\text { lesion on the } \\
\text { lung }\end{array}$ & $\begin{array}{l}\text { Sub- } \\
\text { mandibular } \\
\text { Odem and } \\
\text { eye lid }\end{array}$ & $\begin{array}{l}\text { Swelling of head } \\
\text { region and } \\
\text { incoordination }\end{array}$ & $\begin{array}{l}\text { Lesion on } \\
\text { the mouth, } \\
\text { off feed } \\
\text { and water }\end{array}$ & $\begin{array}{l}\text { Nodular } \\
\text { lesion on } \\
\text { the non- } \\
\text { hair region } \\
\text { of the } \\
\text { body tail, } \\
\text { udder }\end{array}$ & $\begin{array}{l}\text { Sub- } \\
\text { mandibular } \\
\text { Odem poor } \\
\text { BCS and PM } \\
\text { worm on the } \\
\text { liver }\end{array}$ & $\begin{array}{l}\text { Excessive } \\
\text { lacrimation } \\
\text { and off feed } \\
\text { and water }\end{array}$ \\
\hline Common name & Pneumonia & GIP & $\begin{array}{ll}\text { Big head } \\
\text { disease }\end{array}$ & Orf & Pox & Liver fluke & $\begin{array}{l}\text { Pink eye } \\
\text { disease }\end{array}$ \\
\hline Condition and age group of animal affected & $\begin{array}{l}\text { All age } \\
\text { sheep }\end{array}$ & Adult, sheep & All age & Adult & All age & Adult, sheep & All age \\
\hline Seasonality of occurrence & July & $\begin{array}{l}\text { May, Jun, } \\
\text { July }\end{array}$ & $\begin{array}{l}\text { Throughout the } \\
\text { year }\end{array}$ & $\begin{array}{l}\text { Cold } \\
\text { season } \\
\text { July }\end{array}$ & $\begin{array}{l}\text { Jan, Feb, } \\
\text { Mar }\end{array}$ & $\begin{array}{l}\text { Following } \\
\text { rainy season }\end{array}$ & $\begin{array}{l}\text { Throughout } \\
\text { the year }\end{array}$ \\
\hline Breed of animal affected & All & Local & All & Local & All & all & All \\
\hline
\end{tabular}


Citation: Yilma M, Tessema F, Getachew T, Tumato T, Mengistu S, et al. (2016) Rapid Assessment for Livestock Disease Mapping in Ojojie Integrated Water Shed Management Doyogena, District of Southern Ethiopia. J Veterinar Sci Technol 7: 300. doi: 10.4172/2157-7579.1000300

Page 6 of 7

\begin{tabular}{|c|c|c|c|c|c|c|c|}
\hline Main effect of the disease & $\begin{array}{l}\text { death, } \\
\text { weight loss }\end{array}$ & $\begin{array}{l}\text { death, } \\
\text { weight loss, } \\
\text { diarrhea }\end{array}$ & $\begin{array}{l}\text { death, weight } \\
\text { loss }\end{array}$ & $\begin{array}{l}\text { weight } \\
\text { loss }\end{array}$ & $\begin{array}{l}\text { death, } \\
\text { weight } \\
\text { loss }\end{array}$ & $\begin{array}{l}\text { death, } \\
\text { weight loss, } \\
\text { diarrhea }\end{array}$ & weight loss \\
\hline Ethology & MURYA, Air & $\begin{array}{l}\text { Green and } \\
\text { lush pasture }\end{array}$ & Nil & $\begin{array}{l}\text { DUFFA } \\
\text { (plant leaf) }\end{array}$ & Nil & Worm & Nil \\
\hline Treatment and prevention measures / ethno vet practice & $\begin{array}{l}\text { ZEBGEBLE } \\
\text { and Kosho }\end{array}$ & Nil & $\begin{array}{l}\text { Cutting on the } \\
\text { head }+ \text { branding } \\
\text { with hot metal / } \\
\text { knife }\end{array}$ & $\begin{array}{l}\text { Nil } \\
\text { Heal after } \\
\text { infection }\end{array}$ & Nil & Tablet & $\begin{array}{l}\text { ZEBGEBEL } \\
+\quad \text { Garlic } \\
\text { spray on to } \\
\text { the eye }\end{array}$ \\
\hline Degree of effectiveness of the treatment & * & Nil & * & & & $* * *$ & * \\
\hline
\end{tabular}

Table 4: List of most common endemic diseases of shoat. Very effective ${ }^{\star * *}$; a little bit effective*.

\begin{tabular}{|c|c|c|c|c|c|}
\hline Data capture & Disease 1 & Disease 2 & Disease 3 & Disease 4 & Disease 5 \\
\hline Local name & Gandeya & SALAKA & Gamya & $\begin{array}{l}\text { Hangaro } \\
\mathrm{ClCC} /\end{array}$ & chacharsa \\
\hline Clinical signs & $\begin{array}{l}\text { Emaciation, off } \\
\text { feed and water } \\
\text { intake death }\end{array}$ & $\begin{array}{l}\text { Coughing, } \\
\text { submandibular } \\
\text { Odem, emaciation }\end{array}$ & $\begin{array}{l}\text { Sudden change } \\
\text { on feed, lush } \\
\text { pasture, } \\
\text { frequently fall } \\
\text { dawn and stand } \\
\text { up }\end{array}$ & $\begin{array}{l}\text { Inching, } \\
\text { extensive hair } \\
\text { loss and } \\
\text { contagious }\end{array}$ & $\begin{array}{l}\text { Nodular lesion } \\
\text { on the skins of } \\
\text { ventral body } \\
\text { and ozze pus, } \\
\text { emaciation and } \\
\text { death }\end{array}$ \\
\hline Common names & $\begin{array}{l}\text { Systemic } \\
\text { infection }\end{array}$ & Viral infection & Colic / GIP/ & Alopecia & $\begin{array}{l}\text { Epizootic } \\
\text { lypangitis }\end{array}$ \\
\hline Kind of equine affected mostly & Horse & All & All & Horse & Horse \\
\hline Seasonality & $\begin{array}{l}\text { Feb } \\
\text { throughout the } \\
\text { year }\end{array}$ & $\begin{array}{l}\text { Wet season of the } \\
\text { year }\end{array}$ & $\begin{array}{l}\text { Following rainy } \\
\text { season of the } \\
\text { year }\end{array}$ & Feb & $\begin{array}{l}\text { Wet season of } \\
\text { the year }\end{array}$ \\
\hline Major effect of the disease & Death & Death & $\begin{array}{l}\text { Emaciation and } \\
\text { death in chronic } \\
\text { case }\end{array}$ & $\begin{array}{l}\text { Emaciation } \\
\text { and death in } \\
\text { chronic case }\end{array}$ & Death \\
\hline Treatment and prevention measures / ethno vet practice & Nil & $\begin{array}{l}\text { PO rotten chicken } \\
\text { egg }\end{array}$ & $\begin{array}{l}\text { FUGMALATA } \\
\text { tree leaf }\end{array}$ & $\begin{array}{ll}\text { Washing } & \text { with } \\
\text { ENDOI } & \text { and } \\
\text { GULLO } & \text { tree } \\
\text { leaf } & \end{array}$ & $\begin{array}{ll}\text { Washing } & \text { with } \\
\text { ENDOI } & \text { and } \\
\text { GULLO } & \text { tree } \\
\text { leaf } & \end{array}$ \\
\hline Degree of effectiveness of the treatment & & * & *** & ** & * \\
\hline
\end{tabular}

Table 5: List of most common endemic diseases of equine.Very effective ${ }^{\star * *}$; a little bit effective*.

\begin{tabular}{|l|l|}
\hline Data capture & Disease 1 \\
\hline Local name & Kembeshya / FUNGLLE \\
\hline Clinical signs & $\begin{array}{l}\text { Incoordination, coughing, watery diarrhea } \\
\text { and wing paralysis }\end{array}$ \\
\hline Common name & Systemic infection \\
\hline Age of chicken affected & All age \\
\hline Season where the disease occurs & Apr, May \\
\hline Breed of chicken affected & All / improved \\
\hline Effect of the diease prevention & $\begin{array}{l}\text { Bisana leaf }+ \text { BARO }+ \text { Kerosene + BOLE } \\
\text { salt }\end{array}$ \\
\hline Causative agent & Death \\
\hline $\begin{array}{l}\text { Treatment and } \\
\text { measures / ethno vet practice }\end{array}$
\end{tabular}

Degree of effectiveness of the *

treatment

Table 6: List of most common endemic diseases of poultry. Very effective ${ }^{* * *}$; a little bit effective*.

\begin{tabular}{|l|l|l|l|}
\hline Livestock disease & $\begin{array}{l}\text { Morbidity } \\
\text { proportion }(\mathbf{n = 2 0})\end{array}$ & \multicolumn{2}{|l|}{$\begin{array}{l}\text { Mortality condition (n=20) } \\
\text { Disease 3 }\end{array}$} \\
\cline { 3 - 4 } & \multicolumn{2}{|l}{ Die } & Recover \\
\hline Cattle & 1 & 20 & 0 \\
\hline Heticho & 3 & 10 & 10 \\
Bobro & 2 & 12 & 8 \\
Shilgiko & 3 & 15 & 5 \\
Angicho & & & \\
\hline
\end{tabular}


Citation: Yilma M, Tessema F, Getachew T, Tumato T, Mengistu S, et al. (2016) Rapid Assessment for Livestock Disease Mapping in Ojojie Integrated Water Shed Management Doyogena, District of Southern Ethiopia. J Veterinar Sci Technol 7: 300. doi: $10.4172 / 2157-7579.1000300$

Page 7 of 7

\begin{tabular}{|l|l|l|l|}
\hline Keste-damena & 1 & 20 & 0 \\
Murya & 8 & 12 & 8 \\
Gandeya & 2 & 20 & 0 \\
\hline Small ruminants & 6 & 15 & 5 \\
\hline Gansho & 2 & 10 & 10 \\
Lomicho & 1 & 20 & 0 \\
Bokomosso & 3 & 2 & 18 \\
Kurkussa & 2 & 10 & 10 \\
Batarnna & 4 & 10 & 10 \\
Murya & 2 & 1 & 19 \\
Elamosso & &
\end{tabular}

\begin{tabular}{|l|l|l|l|} 
Equine & 10 & 18 & 2 \\
\hline Gandeya & 6 & 2 & 18 \\
SALAKA & 4 & 4 & 16 \\
Gamya & 2 & 20 & 0 \\
Hangaro / CICC I & 2 & 20 & 0 \\
Chacharsa & \begin{tabular}{l}
$|l|$ \\
\hline Poultry
\end{tabular} & 20 & 0 \\
\hline Kembeshya / FUNGLLE & 20 &
\end{tabular}

Table 7: Proportional pilling for herd morbidity and mortality (PPM).

\section{Livestock disease seasonal calendar}

Most of the parasitic diseases occur in the months of May to July (rainy seasons), which happens in these seasons due to favorable conditions for parasites to harbor and liver fluke parasites occur (Figure 5).

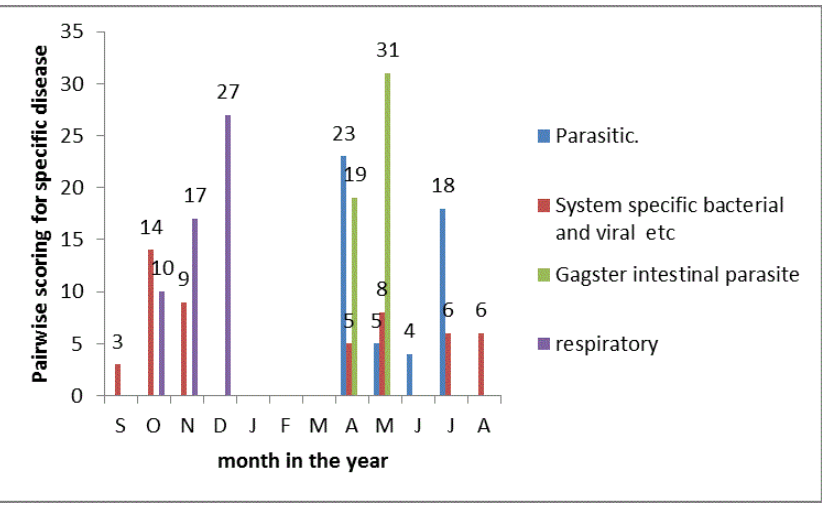

Figure 5: Livestiock disease seasonal calender pair wise scoring on the base of morbdity and mortality of animal in the past one year $(n=50)$.

\section{Conclusion and Recommendation}

This PRA study provided information that will be used as bench mark for livestock disease mapping through disease laboratory diagnosis and conformation. Seasonal disease distributions and livestock production variation is manly associate with the disease enzootic stability, feed gap, and environment. In the study area livestock disease incidence is typically linked directly with temperature change per day / month / season.

Based on the provided information as the bench mark further laboratory intervention should be conducted for disease epidemiology and mapping in the management system.

Intervention strategies should be designed to labiate major production constraints and improve production and productivity of livestock through livestock disease prevention and control.

\section{Acknowledgement}

I want to acknowledge Wolaita Soddo Veterinary Regional Laboratory (WSVRL) for their communications and support in both filed and laboratory work.

"I declare that there is no conflict of interest regarding the publication of this article."

\section{References}

1. Hansen J, Perry B (1994) The epidemiology and control of helminthes parasites of ruminants. A handbook ILRA, Nairobi, Kenya, pp: 171.

2. Blood DC, Henderson JA (1983) Veterinary Medicine. 6th edn. London: Bailliere Tindall, pp: 205-222.

3. Kassa B (2006) Training manual for the control of skin diseases of ruminant livestock in Ethiopia. Addis Ababa, Ethiopia.

4. Food and Agricultural Organization (2009) FAOSTAT data. WHO Expert Committee on Brucellosis, 6th Report and World Health Organization Technical Report Series 740, Geneva, pp: 66-77.

5. CSA (2008) The 2006/07 Ethiopian Agricultural sample enumeration, executive summary report. Addis Ababa, Ethiopia, pp: 114.

6. Sileshi Z, Desalegn L (2009) Sheep and Goat Flock Health. Technical Bulletin, Ethiopia Sheep and Goat Productivity Improvement Program, Addis Ababa, Ethiopia.

7. Areka Agriculture Research Center (2012) Baseline Survey Report of Ojoje Integrated model Watershed Project. Doyogena Woreda, Southern Ethiopia. 